\title{
Impact of MDM2, TP53 and P14ARF Polymorphisms on Endometrial Cancer Risk and Onset
}

\author{
WIOLETTA WUJCICKA ${ }^{1,2}$, AGNIESZKA ZAJĄC ${ }^{3}$ and GRZEGORZ STACHOWIAK ${ }^{3}$ \\ ${ }^{1}$ Scientific Laboratory of the Center of Medical Laboratory Diagnostics and Screening, \\ Polish Mother's Memorial Hospital - Research Institute, Lodz, Poland; \\ ${ }^{2}$ Department of Obstetrics, Perinatology and Gynecology, Polish Mother's \\ Memorial Hospital - Research Institute, Medical University of Lodz, Lodz, Poland; \\ ${ }^{3}$ Department of Operative Gynecology and Gynecologic Oncology, \\ Polish Mother's Memorial Hospital - Research Institute, Lodz, Poland
}

\begin{abstract}
Background/Aim: The aim of this study was to determine the joint effect of single nucleotide polymorphisms (SNPs) of MDM2, TP53, and CDKN2A (P14ARF) genes on the onset and course of endometrial cancer (EC) in postmenopausal women. Materials and Methods: The study group consisted of 144 EC women and 50 non-cancer controls. MDM2 rs22279744, TP53 rs1042522, and P14ARF rs3088440, rs3731217, and rs3731245 SNPs were analysed. Results: The double-SNP combinations T-C, T-T, or T-G in MDM2 SNP 309 and P14ARF polymorphisms decreased EC risk. The triple-SNP combinations T-C-T, T-C-G, or T-T-G in MDM2 SNP and two P14ARF polymorphisms decreased EC risk. The multiple-SNP combination T-C-T-G in MDM2 and three P14ARF polymorphisms decreased EC risk. The G-Arg$C-T-G$ carriers were at increased EC risk, while the T-Arg-C$T$-G carriers were at decreased EC risk. Conclusion: MDM2 SNP309 plays a role in EC onset in postmenopausal women.

Endometrial cancer (EC) being the most common female reproductive tract carcinoma in the developed world, also among Polish women, has the highest prevalence among gynecological invasive neoplasms. EC accounts for about $7 \%$ of new female cancer cases (http://gco.iarc.fr/today/home).
\end{abstract}

This article is freely accessible online.

Correspondence to: Grzegorz Stachowiak, Department of Operative Gynecology and Gynecologic Oncology, Polish Mother's Memorial Hospital - Research Institute, 281/289 Rzgowska St., 93-338 Lodz, Poland. Tel: +48 603099863, Fax: +48 422711510, e-mail: gstach23@interia.pl

Key Words: MDM2, TP53, CDKN2A, P14ARF, single nucleotide polymorphisms (SNPs), endometrial cancer, genetic susceptibility.
There are several risk factors of EC. For example, EC risk was reported to be doubled in women having a first degree relative with EC (1). In recent years, EC research has focused on finding the genetic background of this cancer and on the determination of new genetic risk factors. It is estimated that our current knowledge about the genetic background of EC (e.g. high-risk pathogenic variants in mismatch-repair genes, PTEN, and DNA polymerase genes) explains less than $5 \%$ of the familial EC risk (2).

The newest data (meta-analysis of 12,906 EC cases and 108,979 controls) from genome-wide association studies (GWAS) report on the identification of nine novel genomewide significant loci for EC (3). Using expression quantitative trait locus (eQTL) analyses five candidate causal genes were identified (3). Risk alleles at two of these loci were associated with decreased expression of genes encoding negative regulators of oncogenic signal transduction proteins, such as $S H 2 B 3$ and NF1. GWAS were able to double the number of known EC risk loci, revealing candidate causal genes for future studies (3). Several meta-analyses have also confirmed the role of single nucleotide polymorphism (SNP) 309 located within the $M D M 2$ gene, encoding E3 ubiquitin ligase, in EC tumorigenesis (4-7). In Japanese women with EC, the GG genotype in MDM2 SNP 309 was nonsignificantly associated with an increased risk of EC, while the complex GG-TG and Arg-Arg variants for both MDM2 and TP53 codon 72 polymorphisms, respectively, increased the risk significantly (8). Similarly, in Polish postmenopausal women, MDM2 SNP 309 GG and TP53 rs 1042522 Arg-Arg genotypes, as well as the combined GG and Arg-Arg variants, have been reported to be associated with increased risk of EC (9-11). So far, alterations in p14ARF-MDM2-p53 tumor suppressor pathway have been reported to be associated with tumorigenesis of different cancers, including EC $(12,13)$. High expression of p53 accompanied by low 
levels of MDM2 and p14ARF, have been shown to be possibly correlated with low differentiated primary EC (14). Furthermore, p14ARF expression correlated with histological grade and Ki-67 in EC (13). The expression of p14ARF was also associated with transtubal dissemination of the primary EC (12). However, there are still no data on the possible joint impact of the genetic changes located within all MDM2, TP53 and P14ARF genes on the onset and course of EC. In our previous work, the relationship between EC risk and specific SNPs of MDM2 and TP53 genes was demonstrated (11). In this present study, we aimed to take a reasonable next step in broadening our knowledge on the contribution of genetic factors to EC risk by adding to the analysis the genetic factor P14ARF, which functions in the cell cycle.

\section{Materials and Methods}

The study included multiple-SNP analysis performed on previously obtained data for MDM2 SNP309 rs22279744, TP53 rs1042522, as well as CDKN2A (P14ARF) rs3088440, rs3731217, and rs3731245 polymorphisms (9-11). In brief, genetic data were obtained for 194 postmenopausal women, including 144 (74.2\%) individuals with EC, and 50 (25.8\%) non-cancer control patients. The studied women were treated at the Department of Gynecology and Oncological Gynecology at the Polish Mother's Memorial Hospital - Research Institute in Lodz, from 1997 to 2009 year. Patients were between 28 and 88 years old (the mean age was 59.1 years). Among them, the females with EC were at the age of $61.24 \pm 9.01$ years, while the control individuals at the age of $53.06 \pm 4.75$ years. The study was approved (approval number: 2/2016) by the Research Ethics Committee at the Polish Mother's Memorial Hospital - Research Institute.

DNA extraction. Genomic DNA was extracted from archival paraffin-embedded endometrial tissues, using QIAmp Kit (Qiagen GmbH, Hilden, Germany) in the case of MDM2 and TP53 SNPs and Syngen FFPE DNA Micro Kit (Syngen Biotech, Wroclaw, Poland) in the case of P14ARF SNPs, according to manufacturer's guidelines (9-11).

Genotypes within MDM2, TP53 and P14ARF polymorphisms. Genotypes of the studied MDM2 rs22279744, TP53 rs1042522, as well as P14ARF rs3088440, rs3731217, and rs3731245 SNPs, were determined by polymerase chain reaction-restriction fragment length polymorphism (PCR-RFLP) assays (9-11). Oligonucleotide sequences and PCR conditions performed in the study are presented in Table I. The obtained PCR products were digested overnight with endonucleases appropriate for the analysed polymorphic site, including MspA1I, BstUI, HaeIII, and MvaI, enzymes (Table II). The digestion products were resolved on $2 \%$ agarose gels, stained with ethidium bromide, to determine the genotype profiles of each polymorphism. In the case of P14ARF SNPs, sequencing of selected PCR products representative of distinct genotypes, was also performed, using Sanger's method, to confirm PCR-RFLP results. The chromatograms obtained at the Genomed Joint-Stock Company (Warsaw, Poland) were analysed by the Sequence Scanner 1.0 (Applied Biosystems) program.
Statistical analysis. Distribution of genotypes within MDM2 rs22279744 and TP53 rs1042522 polymorphisms between postmenopausal women with EC and non-cancer controls, analysis for Hardy-Weinberg equilibrium, and association with the disease, have been determined previously (9-11). Additionally, multiple-SNP analysis for the relationship between distinct complex genotypes in MDM2 rs22279744, TP53 rs1042522, as well as P14ARF rs3088440, rs3731217, and rs3731245 SNPs, and the onset and course of EC in postmenopausal women, was performed by the Expectation Maximization (EM) algorithm, using the SNPStats software (https://www.snpstats.net/start.htm). The results were determined as statistically significant at the significance level of $p \leq 0.05$.

\section{Results}

Clinical characteristics of postmenopausal women. The rates of diabetes mellitus, arterial hypertension, body mass index (BMI), menopausal hormone therapy (MHT), and endometrial thickness among postmenopausal women with EC and non-cancer controls were determined. Diabetes mellitus was significantly more prevalent among patients with EC, as compared to women without cancer $(19.0 \% \mathrm{vs}$. $0.0 \%, p \leq 0.05)$. Similarly, arterial hypertension was more prevalent among patients than controls $(52.8 \%$ vs. $33.3 \%$, $p \leq 0.05)$. Regarding BMI, the mean values were significantly higher among patients than controls $\left(30.25 \pm 6.25 \mathrm{~kg} / \mathrm{m}^{2} v s\right.$. $\left.27.43 \pm 5.17 \mathrm{~kg} / \mathrm{m}^{2}, p \leq 0.05\right)$. MHT had similar prevalence rates among women with EC and non-cancer individuals. Considering endometrial thickness, the values over $5 \mathrm{~mm}$ were significantly more frequent among women with EC as compared to controls $(84.3 \%$ vs. $51.1 \%, p \leq 0.001)$.

Complex variants for MDM2 and P14ARF polymorphisms. Occurrence of EC among postmenopausal women with distinct complex variants for both MDM2 309 and CDKN2A (P14ARF) SNPs was determined (Tables III-V). Considering MDM2 SNP 309 and one of the analysed P14ARF SNPs, a significantly decreased risk for EC was observed among carriers of the combined double-SNP T-C (SNP309rs3088440, OR=0.41, 95\%CI=0.26-0.67, $p \leq 0.001$, Table III), T-T (SNP309-rs3731217, OR=0.53, 95\%CI=0.34-0.83, $p \leq 0.05$ ), and $\mathrm{T}-\mathrm{G}$ variants (SNP309-rs3731245, $\mathrm{OR}=0.50$, $95 \% \mathrm{CI}=0.33-0.76, p \leq 0.05)$. Taking into account $M D M 2$ SNP and two of the studied PIAARF polymorphisms, decreased risk for disease was determined among carriers of the combined triple-SNP T-C-T (SNP309-rs3088440-rs3731217, $\mathrm{OR}=0.45,95 \% \mathrm{CI}=0.27-0.76, p \leq 0.05$, Table IV), T-C-G (SNP309-rs3088440-rs3731245, OR=0.42, 95\%CI=0.26$0.69, p \leq 0.001$ ), and T-T-G variants (SNP309-rs3731217$\mathrm{rs} 3731245, \mathrm{OR}=0.55,95 \% \mathrm{CI}=0.35-0.86, p \leq 0.05)$. Moreover, among multiple-SNP variants for $M D M 2$ and all the three P14ARF polymorphisms, the carriers of T-C-T-G combined genotype in SNP309-rs3088440-rs3731217-rs3731245 SNPs, were also at significantly decreased risk for $\mathrm{EC}(\mathrm{OR}=0.46$ 
Table I. Primer sequences, annealing temperatures and PCR products obtained in the assays for genotyping of the polymorphisms located within MDM2, TP53 and P14ARF genes.

\begin{tabular}{|c|c|c|c|c|c|c|}
\hline Gene & $\begin{array}{c}\text { GenBank } \\
\text { Accession No. }\end{array}$ & $\begin{array}{l}\text { SNP } \\
\text { name }\end{array}$ & \multicolumn{2}{|c|}{$\begin{array}{l}\text { Oligonucleotide } \\
\text { sequences }\left(5^{\prime}-3^{\prime}\right)\end{array}$} & $\begin{array}{c}\text { Annealing } \\
\text { temperature }\left({ }^{\circ} \mathrm{C}\right)\end{array}$ & $\begin{array}{l}\text { Amplicon } \\
\text { length (bps) }\end{array}$ \\
\hline \multirow[t]{2}{*}{$M D M 2$} & \multirow[t]{2}{*}{ NC_000012.12 } & \multirow[t]{2}{*}{ rs2279744 } & \multirow{2}{*}{\multicolumn{2}{|c|}{$\begin{array}{l}\text { For: CGCGGGAGTTCAGGGTAAAG } \\
\text { Rev: AGCTGGAGACAAGTCAGGACTTAAC }\end{array}$}} & 62 & 237 \\
\hline & & & & & & \\
\hline \multirow[t]{2}{*}{ TP53 } & \multirow{2}{*}{ NC_000017.11 } & \multirow{2}{*}{ rs 1042522} & \multicolumn{2}{|c|}{ For: TTCACCCATCTACAGTCC } & 62 & 309 \\
\hline & & & \multicolumn{2}{|c|}{ Rev: CTCAGGGCAACTGACCGT } & & \\
\hline \multirow[t]{11}{*}{ P14ARF } & \multirow[t]{11}{*}{ NC_000009.12 } & \multirow[t]{4}{*}{ rs 3088440} & \multirow[t]{2}{*}{ External } & For: TGCTCACTCCAGAAAACTCCA & 55 & 356 \\
\hline & & & & Rev: ATGTGCCACACATCTTTGACC & & \\
\hline & & & \multirow[t]{2}{*}{ Internal } & For: GATGTGCCACACATCTTTGACCT & 55 & 181 \\
\hline & & & & Rev: CTACGAAAGCGGGGTGGGTTGT & & \\
\hline & & \multirow[t]{3}{*}{ rs 3731217} & External & $\begin{array}{l}\text { For: CAGGTGAAGAATGTGATTTGG } \\
\text { Rev: CAAGTGGAAGGTACAATGGAG }\end{array}$ & 55 & 590 \\
\hline & & & \multirow[t]{2}{*}{ Internal } & For: AAAAGGGGGACAACCATTCTC & 55 & 280 \\
\hline & & & & Rev: CCCCTCTCAAATATGCTGTCC & & \\
\hline & & \multirow[t]{4}{*}{ rs 3731245} & \multirow[t]{2}{*}{ External } & For: АСТCTCAAATCATAAACCTGGG & 55 & 440 \\
\hline & & & & Rev: CCCAATGTCTATGTCCTAATCCTC & & \\
\hline & & & \multirow[t]{2}{*}{ Internal } & For: CAAAAATGGGTCCACAAGGTT & 55 & 195 \\
\hline & & & & Rev: CCCAACATAACCCCAAGTGTT & & \\
\hline
\end{tabular}

No.: Number; SNP: single nucleotide polymorphism; bps: base pairs.

$95 \% \mathrm{CI}=0.27-0.79, p \leq 0.05$, Table V). Considering clinical data, the analysed combined variants were distributed similarly between the studied postmenopausal women.

Multiple-SNP variants for MDM2, TP53 and P14ARF polymorphisms. Multiple-SNP analysis performed for all the studied MDM2 SNP309, TP53 rs1042522, and P14ARF rs3088440, rs3731217, and rs3731245 SNPs, showed that the carriers of G-Arg-C-T-G genotype had a significantly increased risk for $\mathrm{EC}(\mathrm{OR}=2.61,95 \% \mathrm{CI}=1.06-6.43, p \leq 0.05)$, while the carriers of T-Arg-C-T-G genotype had a significantly decreased risk for the disease $(\mathrm{OR}=0.42$, $95 \% \mathrm{CI}=0.19-0.93, p \leq 0.05$, Table VI). Similar prevalence rates of the studied combined genotypes were estimated for patients with various clinical characteristics.

\section{Discussion}

In the current study, MDM2 SNP309, TP53 SNP rs1042522, as well as three polymorphisms of P14ARF were found to be jointly involved in the occurrence of EC. The simultaneous presence of MDM2 SNP and distinct one, two, or three P14ARF polymorphisms, decreased EC risk. In various combined genotypes that included double-, triple- or multipleSNPs for MDM2 and P14ARF, the occurrence of the T allele within MDM2 SNP309, and the C allele - within P14ARF rs3088440, the T allele - in rs3731217, as well as the $\mathrm{G}$ allele - in rs3731245 polymorphic sites, was related to diminished risk of EC. A previous study on Polish postmenopausal women with $\mathrm{EC}$ has reported that the GG homozygotes as
Table II. Restriction endonucleases and genotypic profiles used in PCRRFLP assays.

\begin{tabular}{lccc}
\hline Gene & Polymorphism & $\begin{array}{c}\text { Restriction } \\
\text { enzyme }\end{array}$ & $\begin{array}{c}\text { Profile } \\
\text { (bps) }\end{array}$ \\
\hline MDM2 & rs2279744 & MspA1I & TT: 237 \\
& & & TG: $237,189,48$ \\
TF53 & rs1042522 & BstUI & Arg: $179,48,134$ \\
& & & Arg-Pro: $309,175,134$ \\
P14ARF & rs3088440 & HaeIII & Pro: 309 \\
& & & CT: 142,149 \\
& & & TT: 181,39 \\
& rs3731217 & MvaI & TT: 280 \\
& & & TG: $280,154,126$ \\
& rs3731245 & HaeIII & GG: 154,126 \\
& & & AA: 195 \\
& & & AG: $195,123,72$ \\
& & & GG: 123,72 \\
\hline
\end{tabular}

bps: Base pairs.

well as the $\mathrm{G}$ allele in MDM2 SNP309 is significantly associated with the occurrence of EC (9). Additionally, the single-SNP analysis, performed previously at the Polish Mother's Memorial Hospital - Research Institute, on the relationship between the genotypic status of P14ARF polymorphisms and the risk of EC in postmenopausal women, has shown that the CT and TT genotypes, as well as the $\mathrm{T}$ allele within rs3088440 are significantly associated with 
Table III. Relationship between the most common double-SNP combinations for MDM2 and P14ARF polymorphisms and the occurrence of endometrial cancer.

\begin{tabular}{|c|c|c|c|c|c|c|}
\hline \multirow[b]{2}{*}{ P14ARF polymorphism } & \multicolumn{2}{|c|}{ Alleles in $M D M 2$ and $P 14 A R F$ SNPs } & \multicolumn{2}{|c|}{ Prevalence of double-SNP variants } & \multirow[t]{2}{*}{ OR $(95 \% \mathrm{CI})$} & \multirow[t]{2}{*}{$p$-Value } \\
\hline & $M D M 2 \mathrm{SNP} 309$ & P14ARF SNP & Endometrial cancer & Non-cancer controls & & \\
\hline \multirow[t]{4}{*}{ rs3088440 } & G & $\mathrm{C}$ & 0.609 & 0.458 & 1.00 & \\
\hline & $\mathrm{T}$ & $\mathrm{C}$ & 0.197 & 0.442 & $0.41(0.26-0.67)$ & $\leq 0.001$ \\
\hline & G & $\mathrm{T}$ & 0.133 & 0.062 & $1.24(0.55-2.77)$ & 0.610 \\
\hline & $\mathrm{T}$ & $\mathrm{T}$ & 0.062 & 0.038 & $1.31(0.43-4.01)$ & 0.630 \\
\hline \multirow[t]{3}{*}{ rs 3731217} & $\mathrm{G}$ & $\mathrm{T}$ & 0.695 & 0.472 & 1.00 & \\
\hline & $\mathrm{T}$ & $\mathrm{T}$ & 0.259 & 0.428 & $0.53(0.34-0.83)$ & 0.006 \\
\hline & $\mathrm{G}$ & $\mathrm{G}$ & 0.046 & 0.048 & $0.71(0.22-2.32)$ & 0.570 \\
\hline \multirow[t]{2}{*}{ rs3731245 } & $\mathrm{G}$ & $\mathrm{G}$ & 0.713 & 0.520 & 1.00 & \\
\hline & $\mathrm{T}$ & G & 0.255 & 0.480 & $0.50(0.33-0.76)$ & 0.002 \\
\hline
\end{tabular}

SNPs: Single nucleotide polymorphisms; OR: odds ratio; 95\%CI: confidence interval; logistic regression model; $p \leq 0.05$ is considered significant; global double-SNP variants association $p$-value was estimated to be $\leq 0.001$.

Table IV. Association of the most common triple-SNP combinations for MDM2 and P14ARF polymorphisms with the occurrence of endometrial cancer.

\begin{tabular}{|c|c|c|c|c|c|c|}
\hline \multirow[b]{2}{*}{ P14ARF polymorphism } & \multicolumn{2}{|c|}{ Alleles in $M D M 2$ and P14ARF SNPs } & \multicolumn{2}{|c|}{ Prevalence of triple-SNP variants } & \multirow{2}{*}{ OR $(95 \% \mathrm{CI})$} & \multirow[t]{2}{*}{ p-Value } \\
\hline & MDM2 SNP309 & P14ARF SNPs & Endometrial cancer & Non-cancer controls & & \\
\hline \multirow[t]{5}{*}{ rs3088440-rs3731217 } & G & $\mathrm{C}-\mathrm{T}$ & 0.566 & 0.409 & 1.00 & \\
\hline & $\mathrm{T}$ & $\mathrm{C}-\mathrm{T}$ & 0.197 & 0.392 & $0.45(0.27-0.76)$ & 0.003 \\
\hline & G & $\mathrm{T}-\mathrm{T}$ & 0.133 & 0.062 & $1.16(0.51-2.61)$ & 0.730 \\
\hline & $\mathrm{T}$ & $\mathrm{T}-\mathrm{T}$ & 0.057 & 0.038 & $1.13(0.38-3.41)$ & 0.830 \\
\hline & G & C-G & 0.043 & 0.049 & $0.64(0.20-2.13)$ & 0.470 \\
\hline \multirow{4}{*}{ rs3088440-rs3731245 } & G & $\mathrm{C}-\mathrm{G}$ & 0.584 & 0.458 & 1.00 & \\
\hline & $\mathrm{T}$ & $\mathrm{C}-\mathrm{G}$ & 0.194 & 0.442 & $0.42(0.26-0.69)$ & $\leq 0.001$ \\
\hline & G & T-G & 0.129 & 0.062 & $1.26(0.55-2.86)$ & 0.580 \\
\hline & $\mathrm{T}$ & $\mathrm{T}-\mathrm{G}$ & 0.062 & 0.038 & $1.39(0.45-4.25)$ & 0.570 \\
\hline \multirow[t]{3}{*}{ rs $3731217-r s 3731245$} & G & $\mathrm{T}-\mathrm{G}$ & 0.668 & 0.472 & 1.00 & \\
\hline & $\mathrm{T}$ & $\mathrm{T}-\mathrm{G}$ & 0.255 & 0.428 & $0.55(0.35-0.86)$ & 0.009 \\
\hline & G & G-G & 0.045 & 0.048 & $0.70(0.21-2.31)$ & 0.560 \\
\hline
\end{tabular}

SNPs: Single nucleotide polymorphisms; OR: odds ratio; 95\%CI: confidence interval; logistic regression model; $p \leq 0.05$ is considered significant.

EC. In turn, the TG heterozygotes and TG-GG variants in rs3731217 - were correlated with a decreased risk for EC. Considering other cancers, the presence of the GG genotype or G allele within MDM2 SNP309, have also been reported to be associated with an increased risk of esophageal squamous cell carcinoma or estrogen receptor-positive breast cancer, respectively $(15,16)$. Similarly to our outcomes, a meta-analysis performed for 27 case-control studies on the role of MDM SNP309 in gynecological cancers, has shown that the TT homozygotes, as well as the T allele within the polymorphism, are associated with decreased risk of disease
(6). The additional analysis determined that the relationship stayed significant for EC (6). Other meta-analyses also have shown that the GG genotype, as well as the $G$ allele are associated with increased risk of EC $(4,5,7)$. In the case of PI4ARF, similarly to our outcomes, the genotypes GA and AA within rs 3088440 have been shown to be associated with an increased risk of squamous cell carcinoma of the head and neck, and the $\mathrm{T}$ allele with an increased risk of melanoma $(17,18)$. The polymorphism rs 3731217 of PI4ARF has been reported to be correlated with ALL in Caucasians, and the G allele to be protective against paediatric B-cell precursor ALL 
Table V. Relationship between the most common multiple-SNP combinations for MDM2 and P14ARF polymorphisms and the occurrence of endometrial cancer.

\begin{tabular}{|c|c|c|c|c|c|c|c|}
\hline \multicolumn{4}{|c|}{ Alleles in $M D M 2$ and $P 14 A R F$ SNPs } & \multicolumn{2}{|c|}{ Prevalence of multiple-SNP variants } & \multirow[t]{2}{*}{ OR $(95 \% \mathrm{CI})$} & \multirow[t]{2}{*}{$p$-Value } \\
\hline $\begin{array}{l}M D M 2 \\
\text { rs2279744 }\end{array}$ & $\begin{array}{c}P 14 A R F \\
\text { rs } 3088440\end{array}$ & $\begin{array}{c}\text { P14ARF } \\
\text { rs3731217 }\end{array}$ & $\begin{array}{c}P 14 A R F \\
\text { rs } 3731245\end{array}$ & $\begin{array}{l}\text { Endometrial } \\
\text { cancer }\end{array}$ & $\begin{array}{l}\text { Non-cancer } \\
\text { controls }\end{array}$ & & \\
\hline $\mathrm{G}$ & $\mathrm{C}$ & $\mathrm{T}$ & $\mathrm{G}$ & 0.543 & 0.409 & 1.00 & \\
\hline $\mathrm{T}$ & $\mathrm{C}$ & $\mathrm{T}$ & $\mathrm{G}$ & 0.194 & 0.392 & $0.46(0.27-0.79)$ & 0.005 \\
\hline G & $\mathrm{T}$ & $\mathrm{T}$ & $\mathrm{G}$ & 0.130 & 0.062 & $1.18(0.51-2.70)$ & 0.700 \\
\hline $\mathrm{T}$ & $\mathrm{T}$ & $\mathrm{T}$ & $\mathrm{G}$ & 0.057 & 0.038 & $1.20(0.40-3.62)$ & 0.750 \\
\hline $\mathrm{G}$ & $\mathrm{C}$ & G & $\mathrm{G}$ & 0.041 & 0.049 & $0.64(0.19-2.12)$ & 0.470 \\
\hline
\end{tabular}

SNPs: Single nucleotide polymorphisms; OR: odds ratio; 95\%CI: confidence interval; logistic regression model; $p \leq 0.05$ is considered significant; global multiple-SNP variants association $p$-value was estimated to be $\leq 0.0001$.

Table VI. The most common multiple-SNP combinations for the polymorphisms of MDM2, TP53 and P14ARF genes and the occurrence of endometrial cancer.

\begin{tabular}{|c|c|c|c|c|c|c|c|c|}
\hline \multicolumn{5}{|c|}{ Alleles within $M D M 2, T P 53$ and P14ARF SNPs } & \multicolumn{2}{|c|}{ Prevalence of multiple-SNP variants } & \multirow[t]{2}{*}{ OR $(95 \% \mathrm{CI})$} & \multirow[t]{2}{*}{$p$-Value } \\
\hline $\begin{array}{l}M D M 2 \\
\text { rs2279744 }\end{array}$ & $\begin{array}{c}\text { TP53 } \\
\text { rs } 1042522\end{array}$ & $\begin{array}{c}P 14 A R F \\
\text { rs } 3088440\end{array}$ & $\begin{array}{c}P 14 A R F \\
\text { rs } 3731217\end{array}$ & $\begin{array}{c}P 14 A R F \\
\text { rs } 3731245\end{array}$ & $\begin{array}{l}\text { Endometrial } \\
\text { cancer }\end{array}$ & $\begin{array}{c}\text { Non-cancer } \\
\text { controls }\end{array}$ & & \\
\hline G & Pro & $\mathrm{C}$ & $\mathrm{T}$ & G & 0.283 & 0.316 & 1.00 & \\
\hline G & $\operatorname{Arg}$ & $\mathrm{C}$ & $\mathrm{T}$ & $\mathrm{G}$ & 0.261 & 0.094 & $2.61(1.06-6.43)$ & 0.038 \\
\hline $\mathrm{T}$ & Pro & $\mathrm{C}$ & $\mathrm{T}$ & $\mathrm{G}$ & 0.130 & 0.217 & $0.74(0.36-1.51)$ & 0.410 \\
\hline $\mathrm{T}$ & $\operatorname{Arg}$ & $\mathrm{C}$ & $\mathrm{T}$ & $\mathrm{G}$ & 0.062 & 0.173 & $0.42(0.19-0.93)$ & 0.035 \\
\hline G & $\operatorname{Arg}$ & $\mathrm{T}$ & $\mathrm{T}$ & $\mathrm{G}$ & 0.069 & 0.030 & $1.83(0.40-8.36)$ & 0.440 \\
\hline G & Pro & $\mathrm{T}$ & $\mathrm{T}$ & $\mathrm{G}$ & 0.061 & 0.031 & $1.69(0.43-6.63)$ & 0.450 \\
\hline G & Pro & $\mathrm{C}$ & $\mathrm{G}$ & $\mathrm{G}$ & 0.033 & 0.035 & $0.87(0.23-3.26)$ & 0.840 \\
\hline $\mathrm{T}$ & Pro & $\mathrm{T}$ & $\mathrm{T}$ & $\mathrm{G}$ & 0.035 & 0.015 & $1.98(0.30-13.03)$ & 0.480 \\
\hline $\mathrm{T}$ & Arg & $\mathrm{T}$ & $\mathrm{T}$ & $\mathrm{G}$ & 0.023 & 0.023 & $1.36(0.18-10.15)$ & 0.760 \\
\hline
\end{tabular}

SNPs: Single nucleotide polymorphisms; OR: odds ratio; 95\%CI: confidence interval; logistic regression model; $p \leq 0.05$ is considered significant.

$(19,20)$. In turn, among Tunisian children with ALL, the T allele in rs3731217, has been found to be distributed similarly among cancerous and non-cancerous patients (21). The GGGA genotypes of rs3731245 have been shown to be associated with an increased risk of small vessel subtype of ischemic stroke, while the GA-AA genotypes - with reduced risk of chronic benzene poisoning $(22,23)$. Taking into account the functional role of both MDM2 and p14ARF in cell cycle regulation, the N-terminal domain of p14ARF has been reported to bind the C-terminal domain of MDM2, therefore inhibiting its ubiquitin ligase activity (13). The MDM2 protein has also been shown to inhibit the function of p53 tumor suppressor protein, by hiding its activation domain, and by inducing its degradation by the ubiquitinproteasome pathway (24-26). Therefore, the interaction of MDM2 with p14ARF, has been associated with the activation of p53 pathway by preventing its polyubiquitination, nuclear export, and cytoplasmic degradation $(25,27)$. In the current genetic study, the joint impact of polymorphisms in $M D M 2$, TP53 and P14ARF genes on the onset of EC is presented. Combined genotypes including the $\mathrm{G}$ allele within $M D M 2$ SNP309, the Arg allele in TP53 rs1042522 SNP, and the CT-G alleles within P14ARF rs3088440-rs3731217-rs3731245 polymorphisms, respectively, were correlated with an increased risk of EC. However, the genotypes including the $\mathrm{T}$ allele in $M D M 2$ polymorphism were correlated with decreased risk of the cancer. So far, the presence of the $\mathrm{G}$ allele in MDM2 SNP 309 located in the first intron of the gene, has been reported to increase the affinity of the transcription activator $\mathrm{Sp} 1$ to its promoter, resulting in elevated levels of MDM2 mRNA and protein, followed by attenuation of the p53 pathway $(6,28)$. In case of the TP53 gene exon 4 codon 72 Arg>Pro polymorphism (rs1042522), the presence of the Arg allele has been suggested to be seven times more susceptible to E6-mediated ubiquitin-dependent proteolysis as compared to Pro variant $(29,30)$. Regarding 
EC, previous studies have also confirmed the increased risk of cancer for both the Arg allele in TP53 rs1042522, as well as the combination GG and Arg-Arg variants in MDM2 and TP53 SNPs $(10,11)$. The C allele of P14ARF rs3088440 has been found to be associated with the repression of $C D K N 2 A$, while the A allele with an impaired binding of miR-663b to the $C D K N 2 A$ 3'UTR, and therefore with elevated expression of $\mathrm{p} 14 / \mathrm{p} 16$ proteins (31-34). The P14ARF $\mathrm{rs} 3731217$ polymorphism has been suggested to regulate the alternative splicing of $C D K N 2 A$, and the $\mathrm{G}$ allele to be related with higher levels of $C D K N 2 A$ (35). In turn, the rs3731245 polymorphism of $P 14 A R F$, located in the first intron of the gene, has been reported to possibly stay in linkage disequilibrium with other functional polymorphisms of the genomic region of $C D K N 2 A$ or with intron-based transcription regulators, placed in the first intron (22). Considering our results from the multiple-SNP analysis performed for all the studied MDM2, TP53, and P14ARF polymorphisms, the genotype of MDM2 SNP309 out of other SNPs analysed, seems to be the major factor determining the onset of EC in postmenopausal women. Among the studied Polish women, the presence of the $\mathrm{G}$ allele in $M D M 2$ polymorphism may be associated with compromised p53 pathway, therefore increasing the risk of $\mathrm{EC}$, while the $\mathrm{T}$ allele might decrease expression of the encoded MDM2. The E3 ubiquitin ligase may then be bound by p14ARF, enabling the tumor suppressor function of $\mathrm{p} 53$, and resulting in decreased risk of cancer. To the best of our knowledge, this is the first report on the joint effect of MDM2 SNP309, TP53 rs 1042522, and three P14ARF polymorphisms on the onset of EC in postmenopausal women. Further studies to confirm and elucidate the role of the genetic changes within $M D M 2$, TP53 and P14ARF in EC tumorigenesis are required.

\section{Conflicts of Interest}

The Authors have no conflict of interest to disclose regarding this study.

\section{Authors' Contributions}

Wioletta Wujcicka: Design and performance of genetic research, data collection and management, data analysis and interpretation, manuscript writing and editing, final approval of the submitted version of manuscript; Agnieszka Zając: Conception, data collection, revising the article, final approval of the submitted version of manuscript; Grzegorz Stachowiak: Project development, data collection and management, interpretation of data, manuscript writing and editing, final approval of the submitted version of manuscript.

\section{References}

1 Johnatty SE, Tan YY, Buchanan DD, Bowman M, Walters RJ, Obermair A, Quinn MA, Blomfield PB, Brand A, Leung Y,
Oehler MK, Kirk JA, O'Mara TA, Webb PM and Spurdle AB: Family history of cancer predicts endometrial cancer risk independently of Lynch Syndrome: Implications for genetic counselling. Gynecol Oncol 147(2): 381-387, 2017. PMID: 28822557. DOI: 10.1016/j.ygyno.2017.08.011

2 Spurdle AB, Bowman MA, Shamsani J and Kirk J: Endometrial cancer gene panels: clinical diagnostic vs research germline DNA testing. Mod Pathol 30(8): 1048-1068, 2017. PMID: 28452373. DOI: $10.1038 /$ modpathol.2017.20

3 O'Mara TA, Glubb DM, Amant F, Annibali D, Ashton K, Attia J, Auer PL, Beckmann MW, Black A, Bolla MK, Brauch H, Brenner H, Brinton L, Buchanan DD, Burwinkel B, ChangClaude J, Chanock SJ, Chen C, Chen MM, Cheng THT, Clarke CL, Clendenning M, Cook LS, Couch FJ, Cox A, Crous-Bous M, Czene K, Day F, Dennis J, Depreeuw J, Doherty JA, Dörk T, Dowdy SC, Dürst M, Ekici AB, Fasching PA, Fridley BL, Friedenreich CM, Fritschi L, Fung J, García-Closas M, Gaudet MM, Giles GG, Goode EL, Gorman M, Haiman CA, Hall P, Hankison SE, Healey CS, Hein A, Hillemanns P, Hodgson S, Hoivik EA, Holliday EG, Hopper JL, Hunter DJ, Jones A, Krakstad C, Kristensen VN, Lambrechts D, Marchand LL, Liang X, Lindblom A, Lissowska J, Long J, Lu L, Magliocco AM, Martin L, McEvoy M, Meindl A, Michailidou K, Milne RL, Mints M, Montgomery GW, Nassir R, Olsson H, Orlow I, Otton G, Palles C, Perry JRB, Peto J, Pooler L, Prescott J, Proietto T, Rebbeck TR, Risch HA, Rogers PAW, Rübner M, Runnebaum I, Sacerdote C, Sarto GE, Schumacher F, Scott RJ, Setiawan VW, Shah M, Sheng X, Shu XO, Southey MC, Swerdlow AJ, Tham E, Trovik J, Turman C, Tyrer JP, Vachon C, VanDen Berg D, Vanderstichele A, Wang Z, Webb PM, Wentzensen N, Werner HMJ, Winham SJ, Wolk A, Xia L, Xiang YB, Yang HP, Yu H, Zheng W, Pharoah PDP, Dunning AM, Kraft P, De Vivo I, Tomlinson I, Easton DF, Spurdle AB and Thompson DJ: Identification of nine new susceptibility loci for endometrial cancer. Nat Commun 9(1): 3166-05427, 2018. PMID: 30093612. DOI: $10.1038 / \mathrm{s} 41467-018-05427-7$

4 Li Y, Zhao H, Sun L, Huang L, Yang Q and Kong B: MDM2 SNP309 is associated with endometrial cancer susceptibility: a meta-analysis. Hum Cell 24(2): 57-64, 2011. PMID: 21547352. DOI: $10.1007 / \mathrm{s} 13577-011-0013-4$

5 Peng Q, Mo C, Qin A, Lao X, Chen Z, Sui J, Wu J, Zhai L, Yang S, Qin X and Li S: MDM2 SNP309 polymorphism contributes to endometrial cancer susceptibility: evidence from a metaanalysis. J Exp Clin Cancer Res 32: 85, 2013. PMID: 24423195. DOI: $10.1186 / 1756-9966-32-85$

6 Zhang J, Zhang Y and Zhang Z: Association of rs2279744 and rs117039649 promoter polymorphism with the risk of gynecological cancer: A meta-analysis of case-control studies. Medicine (Baltimore) 97(2): e9554, 2018. PMID: 29480845. DOI: 10.1097/MD.0000000000009554

7 Zhao Y, Yang X, Hao X, Pan X, Zhao B, Ma J, Fang J and Zhao M: Common variant on MDM2 contributes to endometrial cancer susceptibility: evidence based on 7 studies. Tumour Biol 35(8): 7555-7560, 2014. PMID: 24792886. DOI: $10.1007 /$ s13277-014-1886-0

8 Yoneda T, Kuboyama A, Kato K, Ohgami T, Okamoto K, Saito $\mathrm{T}$ and Wake N: Association of MDM2 SNP309 and TP53 Arg72Pro polymorphisms with risk of endometrial cancer. Oncol Rep 30(1): 25-34, 2013. PMID: 23624782. DOI: 10.3892/ or.2013.2433 
9 Zajac A, Stachowiak G, Pertynski T, Romanowicz H, Wilczynski $\mathrm{J}$ and Smolarz B: Association between MDM2 SNP309 polymorphism and endometrial cancer risk in Polish women. Pol J Pathol 63(4): 278-283, 2012. PMID: 23359199.

10 Zajac A, Stachowiak G, Smolarz B and Wilczynski JR: Polymorphisms of codon 72 of the TP53 gene in endometrial carcinoma of postmenopausal women. Postepy Hig Med Dosw (Online ) 67: 1312-1318, 2013. PMID: 24379271.

11 Zajac A, Smolarz B, Stachowiak G and Wilczynski JR: TP53 and MDM2 polymorphisms and the risk of endometrial cancer in postmenopausal women. Med Oncol 31(11): 286, 2014. PMID: 25316267. DOI: 10.1007/s12032-014-0286-Z

12 Olcha P, Cybulski M, Skomra D, Obrzut B, Ignatov A, Jozwik M, Schneider-Stock R and Semczuk A: The pattern of p14ARF expression in primary and metastatic human endometrial carcinomas: correlation with clinicopathological features and TP53 pathway alterations. Int J Gynecol Cancer 20(6): 993-999, 2010. PMID: 20683407. DOI: 10.1111/IGC.0b013e3181e76a4d

13 Watanabe J, Nishizaki R, Jobo T, Kamata Y, Hata H, Nishimura Y, Fujisawa T, Okayasu I and Kuramoto H: Expression of tumor suppressor gene product p14ARF in endometrioid adenocarcinoma of the uterine corpus. Int J Gynecol Pathol 23(3): 234-240, 2004. PMID: 15213599.

14 Buchynska LG, Nesina IP and Kashuba EV: Different trends of p53, MDM2 and p14 ARF expression patterns in endometrial adenocarcinomas versus hyperplasia. Exp Oncol 29(4): 287-294, 2007. PMID: 18199985.

15 Hong Y, Miao X, Zhang X, Ding F, Luo A, Guo Y, Tan W, Liu $\mathrm{Z}$ and Lin D: The role of P53 and MDM2 polymorphisms in the risk of esophageal squamous cell carcinoma. Cancer Res 65(20): 9582-9587, 2005. PMID: 16230424, DOI: 10.1158/00085472.CAN-05-1460

16 Karni-Schmidt O, Lokshin M and Prives C: The Roles of MDM2 and MDMX in Cancer. Annu Rev Pathol 11: 617-644, 2016. PMID: 27022975. DOI: 10.1146/annurev-pathol-012414-040349

17 Maccioni L, Rachakonda PS, Bermejo JL, Planelles D, Requena C, Hemminki K, Nagore E and Kumar R: Variants at the 9p21 locus and melanoma risk. BMC Cancer 13: 325, 2013. PMID: 23816148. DOI: 10.1186/1471-2407-13-325

18 Zhang Y, Sturgis EM, Zafereo ME, Wei Q and Li G: p14ARF genetic polymorphisms and susceptibility to second primary malignancy in patients with index squamous cell carcinoma of the head and neck. Cancer 117(6): 1227-1235, 2011. PMID: 21381012. DOI: $10.1002 /$ cncr.25605

19 Sherborne AL, Hosking FJ, Prasad RB, Kumar R, Koehler R, Vijayakrishnan J, Papaemmanuil E, Bartram CR, Stanulla M, Schrappe M, Gast A, Dobbins SE, Ma Y, Sheridan E, Taylor M, Kinsey SE, Lightfoot T, Roman E, Irving JA, Allan JM, Moorman AV, Harrison CJ, Tomlinson IP, Richards S, Zimmermann M, Szalai C, Semsei AF, Erdelyi DJ, Krajinovic M, Sinnett D, Healy J, Gonzalez Neira A, Kawamata N, Ogawa S, Koeffler HP, Hemminki K, Greaves M and Houlston RS: Variation in CDKN2A at 9p21.3 influences childhood acute lymphoblastic leukemia risk. Nat Genet 42(6): 492-494, 2010. PMID: 20453839. DOI: 10.1038/ng.585

20 Zhou X, Liao F, Zhang J, Qin Y, Xu H, Ding Z, Zhang Y and Zhang F: Association of the independent polymorphisms in CDKN2A with susceptibility of acute lymphoblastic leukemia. Biosci Rep 38(3): BSR20180331, 2018. PMID: 29654170. DOI: 10.1042/BSR20180331
21 Gharbi H, Ben H, I, Soltani I, Safra I, Ouerhani S, Bel Haj OH, Teber M, Farah A, Amouri H, Toumi NH, Abdennebi S, Abbes $S$ and Menif S: Association of genetic variation in IKZF1, ARID5B, CDKN2A, and CEBPE with the risk of acute lymphoblastic leukemia in Tunisian children and their contribution to racial differences in leukemia incidence. Pediatr Hematol Oncol 33(3): 157-167, 2016. PMID: 27184773. DOI: 10.3109/08880018.2016.1161685

$22 \mathrm{Hu}$ WL, Li SJ, Liu DT, Wang Y, Niu SQ, Yang XC, Zhang Q, Yu SZ, Jin L and Wang XF: Genetic variants on chromosome 9p21 and ischemic stroke in Chinese. Brain Res Bull 79(6): 431435, 2009. PMID: 19559344. DOI: 10.1016/j.brainresbull. 2009.04.001

23 Sun P, Zhang Z, Wan J, Zhao N, Jin X and Xia Z: Association of genetic polymorphisms in GADD45A, MDM2, and p14 ARF with the risk of chronic benzene poisoning in a Chinese occupational population. Toxicol Appl Pharmacol 240(1): 66-72, 2009. PMID: 19596022. DOI: 10.1016/j.taap.2009.07.003

24 Haupt Y, Maya R, Kazaz A and Oren M: Mdm2 promotes the rapid degradation of p53. Nature 387(6630): 296-299, 1997. PMID: 9153395. DOI: 10.1038/387296a0

$25 \mathrm{Li}$ J, Tang Y, Huang L, Yu Q, Hu G and Yuan X: Genetic Variants in the p14ARF/MDM2/TP53 Pathway Are Associated with the Prognosis of Esophageal Squamous Cell Carcinoma Patients Treated with Radical Resection. PLoS One 11(7): e0158613, 2016. PMID: 27414035. DOI: 10.1371/journal.pone. 0158613

26 Oliner JD, Pietenpol JA, Thiagalingam S, Gyuris J, Kinzler KW and Vogelstein B: Oncoprotein MDM2 conceals the activation domain of tumour suppressor p53. Nature 362(6423): 857-860, 1993. PMID: 8479525. DOI: $10.1038 / 362857 \mathrm{a} 0$

27 Xirodimas D, Saville MK, Edling C, Lane DP and Lain S: Different effects of p14ARF on the levels of ubiquitinated p53 and Mdm2 in vivo. Oncogene 20(36): 4972-4983, 2001. PMID: 11526482. DOI: $10.1038 /$ sj.onc. 1204656

28 Bond GL, Hu W, Bond EE, Robins H, Lutzker SG, Arva NC, Bargonetti J, Bartel F, Taubert H, Wuerl P, Onel K, Yip L, Hwang SJ, Strong LC, Lozano G and Levine AJ: A single nucleotide polymorphism in the MDM2 promoter attenuates the p53 tumor suppressor pathway and accelerates tumor formation in humans. Cell 119(5): 591-602, 2004. PMID: 15550242. DOI: 10.1016/j.cell.2004.11.022

29 Bansal A, Das P, Kannan S, Mahantshetty U and Mulherkar R: Effect of p53 codon 72 polymorphism on the survival outcome in advanced stage cervical cancer patients in India. Indian J Med Res 144(3): 359-365, 2016. PMID: 28139534. DOI: 10.4103/ 0971-5916.198685

30 Storey A, Thomas M, Kalita A, Harwood C, Gardiol D, Mantovani F, Breuer J, Leigh IM, Matlashewski G and Banks L: Role of a p53 polymorphism in the development of human papillomavirus-associated cancer. Nature 393(6682): 229-234, 1998. PMID: 9607760 . DOI: $10.1038 / 30400$

31 Buas MF, Levine DM, Makar KW, Utsugi H, Onstad L, Li X, Galipeau PC, Shaheen NJ, Hardie LJ, Romero Y, Bernstein L, Gammon MD, Casson AG, Bird NC, Risch HA, Ye W, Liu G, Corley DA, Blount PL, Fitzgerald RC, Whiteman DC, Wu AH, Reid BJ and Vaughan TL: Integrative post-genome-wide association analysis of CDKN2A and TP53 SNPs and risk of esophageal adenocarcinoma. Carcinogenesis 35(12): 2740-2747, 2014. PMID: 25280564. DOI: 10.1093/carcin/bgu207 
32 Guo C, Huang Y, Yu J, Liu L, Gong X, Huang M, Jiang C, Liao Y, Huang L, Yang G and Li J: The impacts of single nucleotide polymorphisms in genes of cell cycle and NF-kB pathways on the efficacy and acute toxicities of radiotherapy in patients with nasopharyngeal carcinoma. Oncotarget 8(15): 25334-25344, 2017. PMID: 28445979. DOI: 10.18632/oncotarget.15835

33 Nascimento FP, Cardoso MG, Lindsey SC, Kunii IS, Valente FO, Kizys MM, Delcelo R, Camacho CP, Maciel RM and Dias-DaSilva MR: Analysis of somatic mutations in BRAF, CDKN2A/p16 and PI3KCA in patients with medullary thyroid carcinoma. Mol Med Rep 13(2): 1653-1660, 2016. PMID: 26718898. DOI: $10.3892 / \mathrm{mmr} .2015 .4731$

34 Stenman G, Andersson MK and Andren Y: New tricks from an old oncogene: gene fusion and copy number alterations of MYB in human cancer. Cell Cycle 9(15): 2986-2995, 2010. PMID: 20647765. DOI: $10.4161 /$ cc.9.15.12515
35 Hungate EA, Vora SR, Gamazon ER, Moriyama T, Best T, Hulur I, Lee Y, Evans TJ, Ellinghaus E, Stanulla M, Rudant J, Orsi L, Clavel J, Milne E, Scott RJ, Pui CH, Cox NJ, Loh ML, Yang JJ, Skol AD and Onel K: A variant at 9p21.3 functionally implicates CDKN2B in paediatric B-cell precursor acute lymphoblastic leukaemia aetiology. Nat Commun 7: 10635, 2016. PMID: 26868379. DOI: $10.1038 /$ ncomms 10635
Received January 28, 2019

Revised March 1, 2019

Accepted March 4, 2019 